\title{
Glucose Metabolism in Adipocytes of Obese Offspring of Mild Hyperglycemic Rats ${ }^{1}$
}

\author{
NANCY L. GELARDI, CHUNG-JA M. CHA, AND WILLIAM OH \\ Brown University Program in Medicine, Department of Pediatrics, Women \& Infants Hospital of Rhode Island, \\ Providence, Rhode Island 02905
}

\begin{abstract}
Six pregnant rats were made mildly hyperglycemic by intraperitoneal injection of streptozotocin on d 5 of gestation. Four control rats were injected with citrate buffer. Thirty pups born to experimental dams who had increased birth weight (birth weight $>1.7 \mathrm{SD}$ of mean birth weight of pups from control dams) maintained accelerated growth through 10 wk of age. At 10 wk, oral glucose tolerance tests showed higher glucose and insulin levels than the controls $(n=37)$. In addition to the higher body weight, the experimental rats also had higher fat weight to body weight ratios. Adipocytes of epididymal fat from obese males and periovarian fat from obese females had higher lipid content with significantly larger cell size than the adipocytes of the controls. The adipocytes of macrosomic rats showed attenuated response to insulin-stimulated glucose conversion to total lipid and fatty acid when compared with the responses seen in the adipocytes of the control rats. Interestingly, although the insulin-stimulated glucose conversion to $\mathrm{CO}_{2}$ was similar in macrosomic and control males, the response in the macrosomic female was blunted when compared with that of the control females. Insulin receptor binding capacities of the macrosomic rats were lower than those of the controls, which is consistent with a phenomenon of down-regulation. However, the receptor affinities were higher in the experimental animals than in controls. Therefore, a postreceptor defect may account for the abnormality in glucose metabolism in the obese rats. In conclusion, the abnormal response to oral glucose loading in these experimental obese, hyperinsulinemic rats is due to peripheral tissue insulin resistance that is probably postreceptor in nature. (Pediatr Res 28: 641-645, 1990)
\end{abstract}

Infants of diabetic mothers are at greater risk for perinatal complications than those born to nondiabetic mothers. Specifically, diabetic mothers tend to give birth to abnormally large babies $(1,2)$. Infants with increased birth size have also been shown to be predisposed to the development of obesity in adolescence and early adulthood $(3,4)$. Adolescent obesity has been associated with the manifestation of diabetes mellitus in adulthood (5). Prevention of obesity in these subjects to minimize the incidence of adult-onset diabetes is an important public health problem.

Obesity is characterized anatomically by excessive adipose tissue mass. Glucose utilization studies of obese subjects have

Received September 18, 1989; accepted July 30, 1990.

Correspondence and reprint requests: William Oh, M.D., Department of Pediatrics, Women \& Infants Hospital, 101 Dudley Street, Providence, RI 02905.

Supported by the Perinatal Emphasis Research Center HD 11343-10, funded by National Institute of Child Health and Human Development, Bethesda, MD.

' This work was used as a Master's thesis for N.L.G. at the University of Rhode Island. demonstrated a reduction in the rate of uptake of glucose from the blood (6). It is now generally believed that this abnormal carbohydrate metabolism may be related to the development of insulin resistance of peripheral tissue. We have previously shown that the macrosomic rat pups of mildly hyperglycemic diabetic dams maintain accelerated growth through $12 \mathrm{wk}$ of age and have abnormal glucose tolerance when compared with pups of control dams. The difference in weight between the two groups was shown to be due to increased fat storage in the macrosomic pups (7). We hypothesize that the glucose intolerance in the obese offspring of hyperglycemic rats is due to insulin resistance. A potential tissue that may exhibit the blunted response to insulin stimulation is fat. Using this rat model, the following study was designed to examine the role of adipose tissue in the development of glucose intolerance in the obese offspring of hyperglycemic dams.

\section{MATERIALS AND METHODS}

Pregnant Sprague-Dawley rats were purchased from Taconic Farm, Germantown, NY. The rats were housed individually in wood-chip bedded plastic cages at $23^{\circ} \mathrm{C}$ with light/dark cycles of $12 \mathrm{~h}$ each. All animals had free access to water and commercial rat chow (Purina formula 5001, Ralston Purina, St. Louis, MO) consisting of $23.4 \%$ crude protein, $4.5 \%$ fat, $7.3 \%$ ash, $5.0 \%$ fiber and $49.8 \%$ nitrogen-free extract. On the 5 th $d$ of gestation, streptozotocin $(37 \mathrm{mg} / \mathrm{kg}$ body weight) in $0.1 \mathrm{M}$ citrate buffer $\mathrm{pH} 4.2$, was administered intraperitoneally. Control rats were injected with citrate buffer on the 5th d of gestation. On 13, 16, $18,19,20$, and $21 \mathrm{~d}$ of gestation, between 0830 and $0930 \mathrm{~h}$, dams were weighed and blood samples were collected for determination of plasma glucose and insulin levels. Blood was obtained by cutting off the tip of the tail and squeezing it gently. Rats with plasma glucose levels between 5.55 and $16.65 \mathrm{mmol} /$ $\mathrm{L}$ on 4 of the $5 \mathrm{~d}$ were designated as mildly hyperglycemic and included in the study. The success rate of obtaining mildly hyperglycemic dams in this study was $54 \%$, i.e. six of 11 streptozotocin-treated rats. The five animals excluded from the study were two with plasma glucose concentration below $5.55 \mathrm{mmol} /$ $\mathrm{L}$ and three with plasma glucose concentration in excess of 16.65 $\mathrm{mmol} / \mathrm{L}$.

Pups were delivered spontaneously and nursed by their mothers. The pups were weighed within the first $12 \mathrm{~h}$ of life. Pups from streptozotocin-injected dams whose birth weights were $\geq 1.7$ SD (above the 90th percentile) of the mean birth weights of the control dam pups were considered macrosomic. In this study, the mean birth weight $\pm \mathrm{SD}$ of the control pups was $6.19 \pm 0.38$ g. Therefore, pups from the streptozotocin dams with birth weights $\geq 6.84 \mathrm{~g}$ were included in the study. Sixty-four percent of the pups born to streptozotocin-treated dams had birth weights above $6.84 \mathrm{~g}$ ( 36 of a total of 56 pups).

To ensure similar postnatal nutritional intake, litter sizes were kept between six and 12 pups per nursing dam during the sucking period. Dams giving birth to litters of less than six or greater 
than 12 pups were excluded from the study. Pups were weighed weekly up to $10 \mathrm{wk}$ of age. The sexes of the pups were identified at 2 wk by examining the external genitalia. Pups were weaned at 3 wk of age. Male and female rats were then housed two to three per cage and allowed food and water ad libitum.

At $10 \mathrm{wk}$ of age, oral glucose tolerance tests were performed. Rats were fasted for $15 \mathrm{~h}$ by removing the chow. All oral glucose tolerance tests were done without anesthesia. Basal fasting blood samples were obtained from the rats' tails in the manner previously described. A glucose solution of $5500 \mathrm{mmol} / \mathrm{L}$ in a $3 \mathrm{~g} / \mathrm{kg}$ body weight dose was administered orally via a polyurethane catheter attached to a syringe. After the glucose loading, blood samples were collected from the tails at $0.5,1.0,2.0$, and $3.5 \mathrm{~h}$. The plasma was analyzed for glucose as soon as possible and the remaining plasma was frozen at $-80^{\circ} \mathrm{C}$ for insulin assay. Plasma glucose was determined using the Yellow Springs Instruments Co. (Yellow Springs, OH) model 23A glucose analyzer. Plasma insulin levels were measured by RIA (Amersham Corp., Arlington Heights, IL) using rat insulin standards.

Two to $4 \mathrm{~d}$ after oral glucose tolerance testing, the rats were killed for adipose tissue study. Rats were killed by decapitation between 0800 and $1000 \mathrm{~h}$. Epididymal fat from males and fat surrounding the ovaries and uterine horns from females was removed, washed in warm saline, and weighed. Fat from one to two males or two to three females was pooled to ensure adequate sample size. Blood was collected via cardiac puncture and the plasma was frozen at $-80^{\circ} \mathrm{C}$ for glucose and insulin assay.

Adipocyte isolation and number. Adipocytes were prepared by digestion with $5.0 \mathrm{~mL} / \mathrm{g}$ tissue of solution containing $530 \mathrm{U} / \mathrm{mg}$ $(0.33 \mathrm{mg} / \mathrm{mL}$ collagenase $), 4.0 \mathrm{mg} / \mathrm{mL} \mathrm{BSA}$, and $5.55 \mathrm{mmol} / \mathrm{L}$ glucose, for $1 \mathrm{~h}$ at $37^{\circ} \mathrm{C}$ in a shaking water bath. After digestion, cells were strained through a $250-\mu \mathrm{m}$ nylon mesh filter and washed three times with albumin/collagenase-free buffer. Cells were then resuspended in albumin/collagenase-free buffer. Adipocyte counts were performed using Oil-Red-O (Sigma Chemical Co., St. Louis, MO), which colored intact adipocytes dark red. Cells were then counted using a hemocytometer. Additionally, a series of five samples were run in parallel on a hemocytometer and on a Becton Dickinson (Parsippany, NJ) FACS 440 laser flow cytometer. One aliquot of the cell suspension was counted under the microscope as previously described, another was incubated 5-10 min in fluorescein diacetate and the number of fluorescent cells counted in the flow cytometer.

The counts in the five samples were $1.97 \times 10^{5}, 1.8 \times 10^{5}, 8.5$ $\times 10^{4}, 1.6 \times 10^{5}$, and $2.1 \times 10^{6}$, and $2.2 \times 10^{5}, 2.2 \times 10^{5}, 1.1 \times$ $10^{5}, 1.9 \times 10^{5}$ and $2.7 \times 10^{6}$ cells $/ \mathrm{mL}$ for flow cytometer and hemocytometer, respectively. The hemocytometer counts ranged from 12.5 to $22.7 \%$ higher than the flow cytometer, well within an acceptable range for this study. The cell count is expressed as cells/g fat tissue.

Adipocyte total lipid content. An aliquot of cell suspension $(0.5$ $\mathrm{mL}$ ) was filtered through no. 5 filter paper and rinsed with chloroform:methanol $(2: 1)$ to a final volume of $10 \mathrm{~mL}$. Total lipid was then extracted overnight according to the methods of Folch and Stanley (8). After siphoning off the upper layer, aliquots of the lower layer were transferred to preweighed vials and dried. The difference in the weight of the empty vials and the vials containing dried residue was used to obtain lipid content of the sample.

Glucose oxidation. The ability of isolated adipocytes to oxidize glucose was determined according to the methods of Rodbell (9). Adipocytes were incubated for $2 \mathrm{~h}$ at $37^{\circ} \mathrm{C}$ in tubes containing Krebs-Ringer bicarbonate buffer, $\mathrm{pH} 7.4$, with insulin in concentrations ranging from 0.03 to $2.5 \mathrm{nM}$ and $\mathrm{U}^{14} \mathrm{C}$-labeled glucose (0.93-1.33 × $10^{10} \mathrm{~Bq} / \mathrm{mmol}$; New England Nuclear, Boston, MA). Tubes were gassed for $30 \mathrm{~s}$ with $95 \% \mathrm{O}_{2} \quad 5 \% \mathrm{CO}_{2}$ and capped with rubber stoppers fitted with plastic wells containing filter paper saturated with hyamine hydroxide. After the termination of incubation, the filter paper was transferred to scintillation vials and counted.
The adipocytes were transferred to $10 \mathrm{~mL}$ of chloroform:methanol (2:1) and total lipid was extracted as previously described. Aliquots of the lower layer were dried and counted for total ${ }^{14} \mathrm{C}$-lipid content.

To measure glucose carbon incorporation into fatty acids, an aliquot of the lipid extract was saponified by adding alcoholic$\mathrm{KOH}(95 \%$ ethanol and $40 \% \mathrm{KOH})$ and heating for $1 \mathrm{~h}$ at $80^{\circ} \mathrm{C}$ in a water bath (10). After adding water and hexane, an aliquot of the lower phase was dried and counted for radioactivity to determine fatty acid content.

Insulin binding studies. An aliquot of the isolated fat cells was suspended in Krebs-Ringer phosphate buffer, $\mathrm{pH} 7.4$, containing $2 \%$ serum albumin and $5 \mathrm{mM}$ glucose. The cells were then incubated for $1 \mathrm{~h}$ at $23^{\circ} \mathrm{C}$ with ${ }^{125} \mathrm{I}$-labeled insulin $\left(8.14 \times 10^{7}\right.$ $\mathrm{Bq} / \mathrm{mmol}$, New England Nuclear) with the addition of unlabeled insulin in concentrations ranging from 0.033 to $19 \mathrm{nM}$. Incubation was terminated by adding excess buffer and centrifuging for $30 \mathrm{~min}$ at $3000 \times g$. The tubes were rinsed twice and recentrifuged. The pellets were counted in a gamma counter. In addition, a series of binding experiments were also terminated by centrifuging a $100-\mu \mathrm{L}$ aliquot of cells with $200 \mu \mathrm{L}$ of oil. The two techniques yielded similar values for binding affinity and capacity. All studies were done in triplicate.

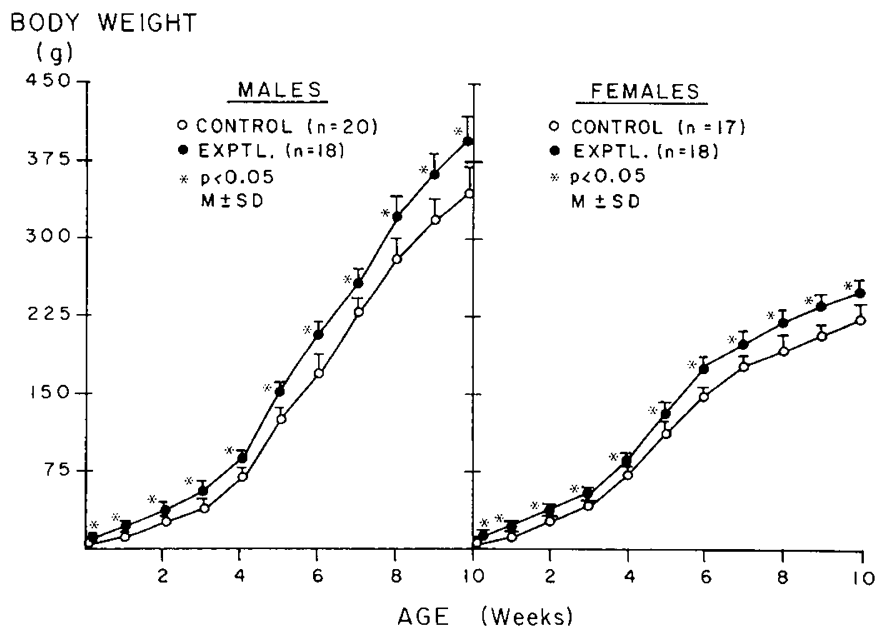

Fig. 1. Changes in body weight in male and female rats through the first 10 wk of age.
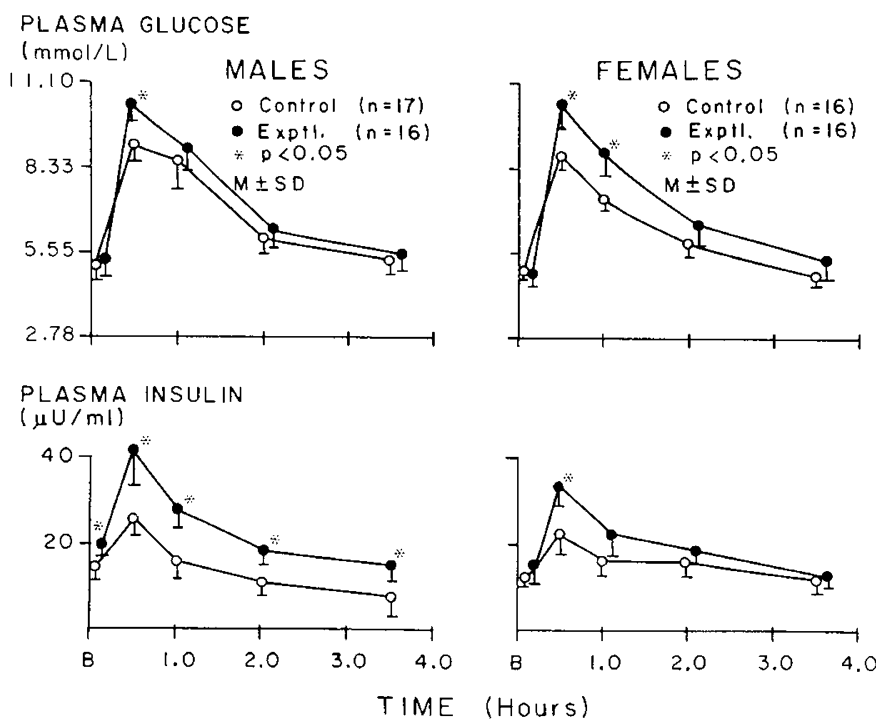

Fig. 2. Oral glucose tolerance curves in male and female rats at 10 wk of age. Three $\mathrm{g} / \mathrm{kg}$ body weight of glucose was given orally immediately after blood sampling for 15 -h fasting baseline $(B)$ values. 
GLUCOSE METABOLISM IN ADIPOCYTES OF OBESE RATS

Table 1. Insulin:glucose ratio during oral glucose tolerance test in 10-wk-old rats*

\begin{tabular}{lccccc}
\hline & Fasting & $0.5 \mathrm{~h}$ & $1.0 \mathrm{~h}$ & $2.0 \mathrm{~h}$ & $3.5 \mathrm{~h}$ \\
\hline Male & & & & & \\
Control $(n=17)$ & $3.03 \pm 0.80$ & $3.03 \pm 0.70$ & $2.20 \pm 1.06$ & $2.20 \pm 1.06$ & $1.60 \pm 0.94$ \\
Experimental $(n=16)$ & $3.60 \pm 0.35$ & $3.99 \pm 1.07$ & $3.05 \pm 0.97$ & $3.02 \pm 0.63$ & $2.62 \pm 0.86$ \\
$p$ & $\mathrm{NS}$ & $<0.05$ & $<0.05$ & $<0.05$ & $<0.05$ \\
Female & & & & \\
Control $(n=16)$ & $2.70 \pm 0.41$ & $2.67 \pm 0.60$ & $2.12 \pm 0.42$ & $2.82 \pm 0.49$ & $2.46 \pm 0.56$ \\
Experimental $(n=16)$ & $3.73 \pm 1.44$ & $3.38 \pm 0.60$ & $2.21 \pm 0.46$ & $2.86 \pm 0.54$ & $2.37 \pm 0.31$ \\
$p$ & $\mathrm{NS}$ & $<0.05$ & $\mathrm{NS}$ & $\mathrm{NS}$ & $\mathrm{NS}$ \\
\hline
\end{tabular}

* Values are mean $\pm \mathrm{SD}$.

Table 2. Plasma glucose and insulin, body wt and fat wt, and fat cell number and fat cell size of macrosomic and control rats*

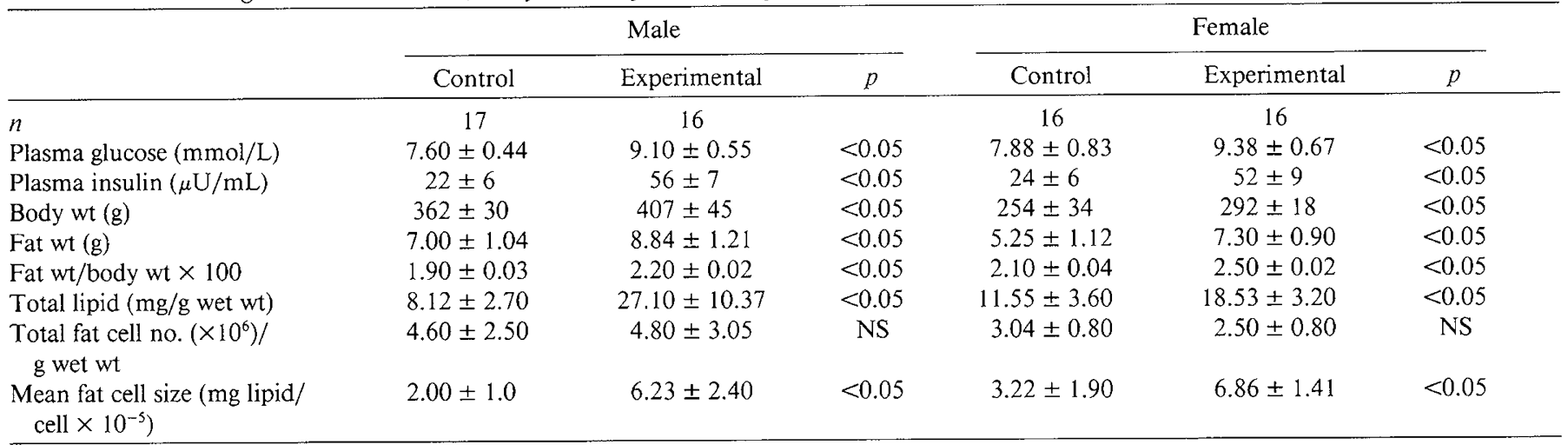

$*$ Values are mean $\pm \mathrm{SD}$.

Statistical analysis. Statistical significance for changes in body weight with reference to age was analyzed by repeated-measures analysis of variance. Differences in oral glucose tolerance and glucose conversion to $\mathrm{CO}_{2}$, triglyceride, and fatty acid with reference to insulin concentration were analyzed by analysis of variance (11). Insulin receptor binding competition curves were analyzed according to the methods of Scatchard (12).

\section{RESULTS}

As we have shown previously (7), the streptozotocin-treated pregnant dams had significantly higher plasma glucose and lower plasma insulin levels during the last week of gestation. Figure 1 shows the body weight changes of the pups through $10 \mathrm{wk}$ of age. Both male and female pups of streptozotocin-treated dams, who were macrosomic at birth, maintained higher body weights throughout the first 10 wk of age. In Figure 2, oral glucose tolerance tests at $10 \mathrm{wk}$ of age show that the male rats in the experimental group had higher plasma glucose levels at $0.5 \mathrm{~h}$ after glucose loading when compared with control males. The

$$
{ }^{14} \mathrm{C} \text { - GLUCOSE CONVERSION TO } \mathrm{CO}_{2}
$$

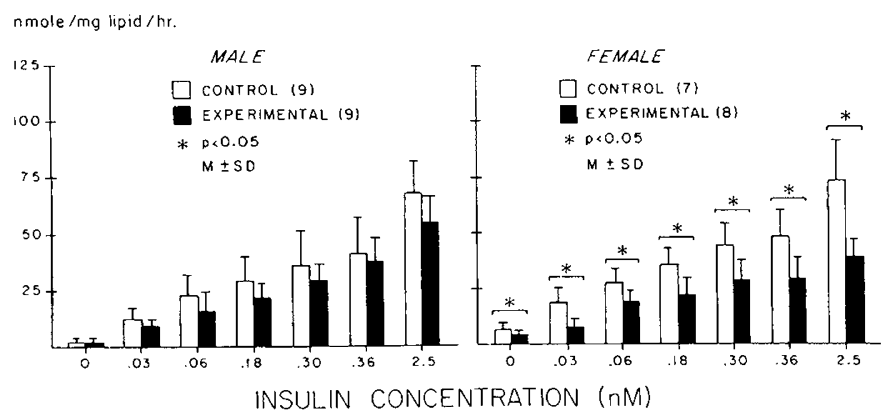

Fig. 3. Insulin-stimulated ${ }^{14} \mathrm{C}$-glucose conversion to $\mathrm{CO}_{2}$ in adipocytes of male and female rats. The numbers in parentheses represent numbers of incubations that reflect pooling of fat cells from two to three rats in each group.

\section{${ }^{14} \mathrm{C}$-GLUCOSE CONVERSION TO TRIGLYCERIDES}

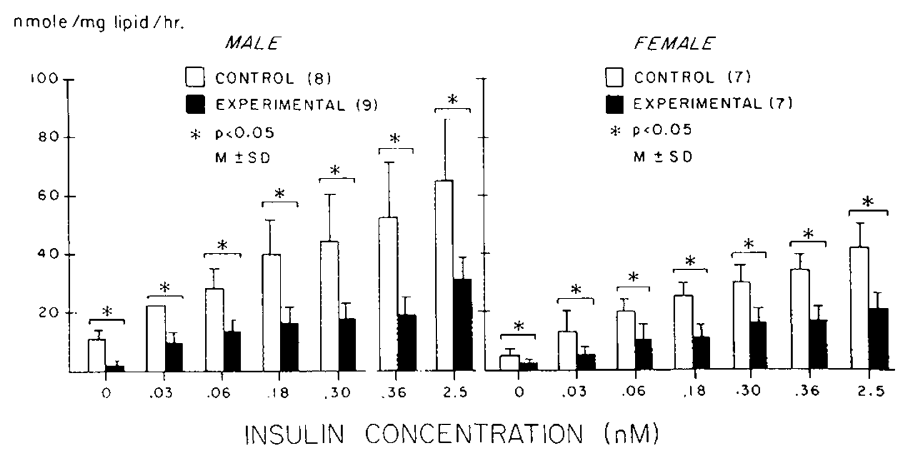

Fig. 4. Insulin-stimulated ${ }^{14} \mathrm{C}$-glucose conversion to triglyceride by adipocytes of male and female rats. The numbers in parentheses represent numbers of incubations that reflect pooling of fat cells from two to three rats in each group.

plasma insulin levels of the experimental males were significantly elevated at all time points. Female experimental rats showed elevated plasma glucose levels at 0.5 and $1.0 \mathrm{~h}$ and higher plasma insulin levels at $0.5 \mathrm{~h}$ versus control females. The insulin to glucose ratios are shown in Table 1 . In males, the ratios of the experimental group were significantly higher at all time points after the glucose load. For females, the only significant difference was at $0.5 \mathrm{~h}$, where the experimental group was higher.

Thirty-two rats from the experimental group and 33 from the control group were killed for in vitro adipocyte studies. Table 2 shows that the experimental animals had elevated plasma glucose and insulin levels when they were killed. Body weights, fat weight, and the ratio of fat weight to body weight in experimental males and females were higher than those in the controls. The total lipid content of samples taken from the experimental animals was significantly greater than that of controls. Also, mean fat cell sizes of both experimental males and females were greater than those of their respective controls. 

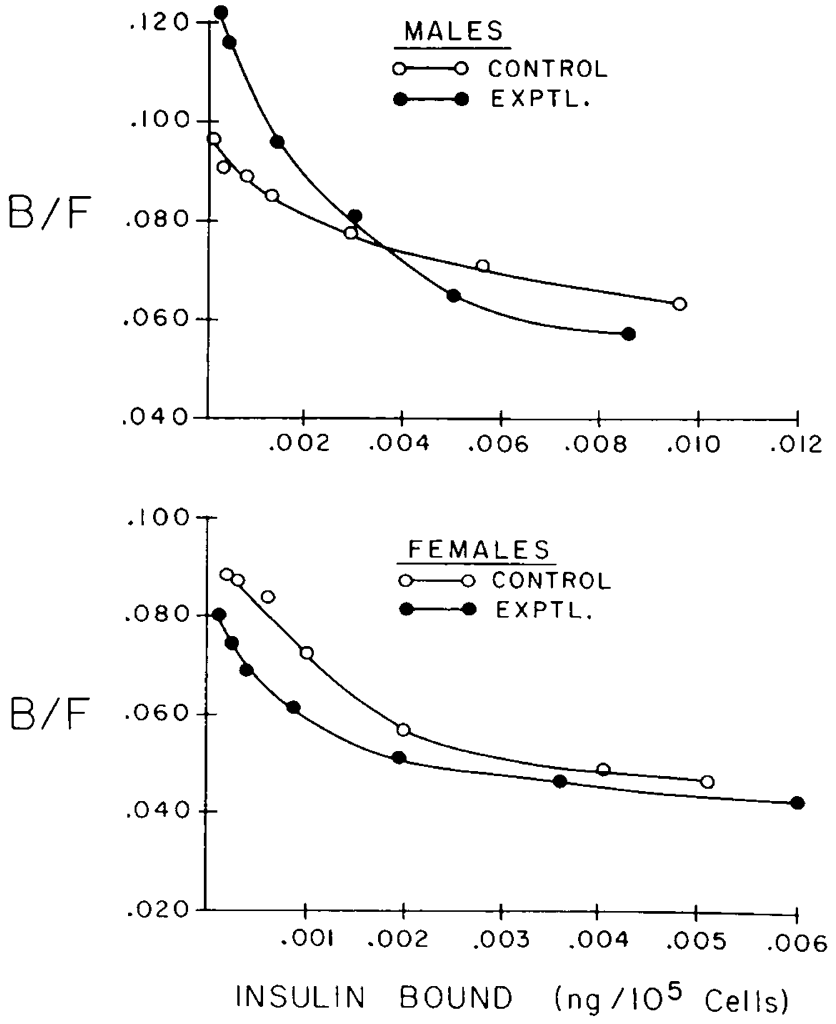

Fig. 5. Representative adipocyte insulin-binding curves of male and female rats.

Table 3. Adipocyte insulin receptor characteristics*

\begin{tabular}{lccccc}
\hline & \multicolumn{2}{c}{$\begin{array}{c}\text { Binding capacity } \\
\left(\times 10^{-14} \mathrm{~mol} / \mathrm{mg} \text { lipid }\right)\end{array}$} & & \multicolumn{2}{c}{$\begin{array}{c}\text { Affinity constant } \\
\left(\times 10^{10} \mathrm{M}^{-1}\right)\end{array}$} \\
\cline { 2 - 3 } & $\begin{array}{c}\text { Primary } \\
\text { site }\end{array}$ & $\begin{array}{c}\text { Secondary } \\
\text { site }\end{array}$ & & $\begin{array}{c}\text { Primary } \\
\text { site }\end{array}$ & $\begin{array}{c}\text { Secondary } \\
\text { site }\end{array}$ \\
\hline $\begin{array}{c}\text { Male } \\
\text { Control } \\
(n=7)\end{array}$ & $0.23 \pm 0.15$ & $0.40 \pm 0.24$ & $19.8 \pm 9.0$ & $6.6 \pm 5.3$ \\
$\begin{array}{c}\text { Experimental } \\
(n=7)\end{array}$ & $0.06 \pm 0.03 \dagger$ & $0.53 \pm 0.36$ & $39.0 \pm 13.0 \dagger 7.9 \pm 3.5$ \\
$\begin{array}{c}\text { Female } \\
\text { Control } \\
(n=6)\end{array}$ & $1.54 \pm 0.65$ & $3.60 \pm 2.20$ & $21.5 \pm 1.97$ & $4.0 \pm 0.75$ \\
$\begin{array}{c}\text { Experimental } \\
(n=6)\end{array}$ & $0.26 \pm 0.12 \dagger$ & $3.65 \pm 1.40$ & $38.1 \pm 9.10 \dagger$ & $3.1 \pm 0.94$ \\
\hline
\end{tabular}

$*$ Values are mean $\pm \mathrm{SD}$.

$\dagger p<0.05$.

The response to insulin-stimulated $\mathrm{U}_{-}{ }^{14} \mathrm{C}$-glucose conversion to $\mathrm{CO}_{2}$ by adipocytes is shown in Figure 3. No significant differences were seen between the two groups of male rats. Experimental females, however, had lower baseline values as well as a significantly blunted response to insulin stimulation when compared with controls. Figure 4 shows $\mathrm{U}-{ }^{14} \mathrm{C}$-glucose conversion to triglycerides. Both male and female experimental animals showed a significantly lower response to insulin stimulation at all insulin concentrations used in the study. A similar pattern of reduced response to insulin was also observed with $\mathrm{U}-{ }^{14} \mathrm{C}$-glucose converted to fatty acids.

Representative adipocyte insulin receptor binding curves are shown in Figure 5. The derived adipocyte insulin receptor binding characteristics are shown in Table 3 . At the primary binding site, both experimental males and females have an increased affinity constant compared with controls. The binding capacity of the experimental animals was significantly reduced when compared with controls.

\section{DISCUSSION}

This study was designed to investigate the possible mechanism of abnormal glucose metabolism in offspring of rats rendered hyperglycemic during pregnancy. By using streptozotocin treatment to obtain mild maternal hyperglycemia in pregnant rats, we were successful in obtaining a colony of obese, hyperinsulinemic offspring $(13,14)$. The abnormal glucose tolerance test of the male and female experimental animals is consistent with our previous work (14). In the current study, we found that in the males the insulin response to the glucose challenge was elevated at all points during the test and that this was associated with a normal glucose response. This was not the case for the female rats. This gender difference is of interest and the reason for it remains to be investigated.

Experimental animals had a higher ratio of fat weight to body weight than the controls (Table 2). The data show that there was no difference in the total number of cells per $g$ of tissue, however, the mean adipose cell size, as measured by lipid content, of experimental males and females was 2.5-3.0 times larger than that of control males and females, respectively. The differences in fat weight/body weight ratios therefore are due primarily to increased lipid content in the obese animals, not increased adipocyte number.

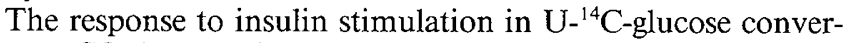
sion to $\mathrm{CO}_{2}$ by experimental males was similar to that of control males (Fig. 3). This is in agreement with previous finding of Olefsky (15) that large adipocytes of obese males have Krebs cycle activity that is relatively normal. Experimental females, however, seem to have a defect in glucose oxidation. There are significantly lower amounts of glucose converted to $\mathrm{CO}_{2}$ by their adipocytes at basal levels. They also exhibit lower amounts of $\mathrm{CO}_{2}$ evolved from glucose during incubation with increasing concentrations of insulin as compared with control females. This finding is consistent with the observation that the experimental male rats had a smaller rise in plasma glucose concentration during the oral glucose tolerance test than the experimental females in this and our previous studies $(7,14)$. The gender difference is again of interest but the reason is unclear.

Glucose oxidation, however, represents only one of the pathways of glucose metabolism in adipocytes. Another is the conversion of glucose to triglyceride and fatty acid. In this respect, our data in the experimental group are consistent with those of others (16-19), which show reduced conversion of glucose to both triglyceride and fatty acid in both male and female subjects.

The decrease in glucose conversion by adipocytes of the experimental animals at $10 \mathrm{wk}$ corresponds to the time when these animals first show glucose intolerance (7). However, because the adipocytes of the obese animals have approximately three times as much lipid as those from controls, the insulin "resistance" demonstrated at this age is per cell surface area or volume. It may be necessary to follow these animals for a longer time to see insulin resistance on a per cell basis. It may also be that by 10 wk the obese animals are expressing a biochemical feedback mechanism to regulate triglyceride production to keep their already grossly enlarged adipocytes from expanding further. Several investigators have shown that enlarged adipocytes have a diminished acetyl CoA carboxylase content resulting in diminished fatty acid synthesis and a subsequent inhibition of pentose shunt pathway activity $(17,20-22)$. Whether or not this mechanism is used by the obese animals in our study remains to be investigated.

Scatchard analysis (12) of the insulin receptor binding competition curves (Table 3 ) shows what previous investigators have seen $(23,24)$ - that the binding capacity at the high affinity site for both experimental males and females is significantly lower than for controls. This result was expected due to the elevated levels of plasma insulin in these animals. We have also shown that the affinity constants for the high affinity site are higher in the experimental animals. The consequences of a lower receptor 
capacity and higher binding affinity are suggestive of an appropriate insulin-receptor interaction for glucose metabolism. The data are interpreted to suggest that the observed defect in glucose metabolism is probably postreceptor in nature.

Although this study was not designed specifically to examine the gender difference in the abnormality of glucose metabolism associated with obesity, it is interesting that the experimental females seen to be more affected than experimental males. These gender differences are significant and require more in-depth investigation into the role of sex hormones in glucose metabolism in these experimental animals.

In summary, our study shows that the abnormal glucose tolerance observed in obese, hyperinsulinemic offspring of mildly hyperglycemic mothers is associated with a blunted insulin response in the adipocyte that is probably postreceptor in nature.

\section{REFERENCES}

1. Farquhar JW 1976 The infant of the diabetic mother. Clin Endocrinol Metab 5:237-264

2. Cowett RM, Schwartz R 1982 The infant of the diabetic mother. Pediatr Clin North Am 29:1213-1231

3. Vohr BR, Lipsitt LP, Oh W 1980 Somatic growth of children of diabetic mothers with reference to birth size. J Pediatr 97:196-199

4. Pettitt DJ, Baird HR, Aleck KH, Bennett PH, Knowler WC 1983 Excessive obesity in offspring of Pima Indian women with diabetes during pregnancy. N Engl J Med 308:242-245

5. Lebovitz HE 1984 Etiology and pathogenesis of diabetes mellitus. Pediatr Clin North Am 31:521-530

6. Salans LB, Knittle JL, Hirsch J 1968 The role of adipose cell size and adipose tissue insulin sensitivity in the carbohydrate intolerance of human obesity. J Clin Invest 47:153-165

7. Oh W, Gelardi NL, Cha C-J 1988 Mild maternal hyperglycemia during pregnancy: its effect on growth and carbohydrate metabolism in the offspring. Metabolism 37:1146-1151

8. Folch J, Stanley LM 1957 A simple method for the isolation and purification of total lipids from animal tissue. J Biol Chem 226:497-509

9. Rodbell M 1964 Metabolism of isolated fat cells. I. Effects of hormones on glucose metabolism and lipolysis. J Biol Chem 239:375-380

10. Dole VP, Meinertz H 1960 Microdetermination of long chain fatty acids in plasma and tissue. J Biol Chem 235:2595-2599

11. Snedecor GW, Cochran WG 1967 Statistical Methods, 6th Ed. The Iowa State University Press, Ames, lowa

12. Scatchard G 1949 The attraction of proteins for small molecules and ions. Ann NY Acad Sci 51:660-672

13. Catlin EA, Cha C-JM, Oh W 1985 Postnatal growth and fatty acid synthesis in insulin-induced macrosomic rat pups. Metabolism 34:1110-1114

14. Cha C-JM, Gelardi NL, Oh W 1987 Accelerated growth and abnormal glucose tolerance in young female rats exposed to fetal hyperinsulinemia. Pediatr Res 21:83-87

15. Olefsky JM 1977 Mechanism of decreased insulin responsiveness of large adipocytes. Endocrinology 100:1169-1177

16. Espositio J, Thurman L, Owens JL 1974 Metabolic patterns and insulin responsiveness of enlarging fat cells. J Lipid Res 15:332-338

17. Richardson D, Czech MP 1978 Primary role of decreased fatty acid synthesis in insulin resistance of large rat adipocytes. Am J Physiol 234(2)E182-E189

18. Kolterman OG, Insel J, Saekow M, Olefsky JM 1980 Mechanisms of insulin resistance in human obesity, evidence for receptor and postreceptor defects. J Clin Invest 65:1272-1284

19. Prager R, Wallace P, Olefsky JM 1987 Hyperinsulinemia does not compensate for peripheral insulin resistance in obesity. Diabetes 36:327-334

20. Kather H, Rivera M, Brand K 1972 Interrelationship and control of glucose metabolism and lipogenesis in isolated fat-cells. Biochem J 128:1097-1 102

21. Saggerson ED, Greenbaum AL 1970 The regulation of triglyceride synthesis and fatty acid synthesis in rat epididymal adipose tissue. Biochem J 1 19:193219

22. Eggleston LV, Krebs HA 1974 Regulation of the pentose phosphate cycle. Biochem J 138:425-435

23. Olefsky JM, Reaven GM 1975 The effect of age and obesity on insulin binding to isolated adipocytes. Endocrinology 96:1486-1498

24. Livingston JN, Cuatrecasas P, Lockwood DH 1972 Insulin insensitivity of large fat cells. Science 77:626-628 